\title{
ANALYSIS OF FACTORS INFLUENCE DOCTOR'S DECISION IN CHOOSING PATIENT'S REFERRAL TO dr. SOEPRAOEN ARMY HOSPITAL MALANG
}

\author{
Sebastian Augustinus Budijono ${ }^{1}$, Sandu Siyoto², Siti Farida Noor Laila ${ }^{3}$ \\ ${ }^{1}$ Magister of Public Health Program, Stikes Surya Mitra Husada Kediri, Indonesia \\ ${ }^{2,3}$ Lecturer of Magister of Public Health Program, Stikes Surya Mitra Husada Kediri, Indonesia \\ Corresponding author: Sebastian Augustinus Budijono (sebastian_agustinus@gmail.com)
}

\begin{abstract}
The importance of the role of health services causes the quality of health services to be improved because of the needs of the community or individuals for health. Second-level health services can only be given for referral from first-level health services. Third-level health services can only be given for referral from second- or first-level health services, except in emergency situations. Based on this, it can be seen that the first level Health Service Provider (PPK) has a very important role in the health care system in Indonesia. The purpose of this study was to find out the factors underlying the doctors to refer their patients to the dr. Soepraoen Army Hospital Malang. The research design used is quantitative research with a cross sectional approach. The sampling technique used was saturated sampling by taking 100 doctors as the study sample. The data analysis technique of this study uses linear regression by using an $\alpha$ value of 0.05 . The results showed that hospital facilities had a significant effect on choosing a referral with a p-value of 0,000 with a $t$-count of 4,300, the availability of drugs had a significant effect on choosing a referral with a p-value of 0,000 with a t-count of 2,557, the type of disease has a significant effect on choosing a referral with a p-value of 0,000 with a t-count value of 2,435, and on physician competence has a significant effect on choosing a referral with a p-value of 0,000 and a t-count value of 2,327, and simultaneously for each facility variable, drug availability, type of disease and physician competence can have a significant effect on choosing a referral. and found that the dominant factor influencing the decision to choose referral is the facility factor. The low analysis of factors that influence the doctor's decision in choosing a patient's referral to dr. Soepraoen Army Hospital Malang can be minimized by further increasing the indicator indicators of each variable that is considered still low.
\end{abstract}

Keywords: Doctor decision factors, patient referral

Copyright $\subset 2019$ Stikes Surya Mitra Husada. All right reserved.

\section{INTRODUCTION}

Basically, referrals are the delegation of authority and responsibility for public health problems and cases of disease carried out reciprocally both vertically and horizontally including facilities, technology references, expert referrals, operational referrals, case references, scientific and referral references laboratory examination materials (Permenkes RI No. 922 of 2008). Based on Minister of Health Regulation No. 001 of 2012 concerning Individual Health Service Referral System states that health services are carried out in stages so that the referral system is an obligation that must be carried out by KDP 1 . KDP 1 if unable to provide special services that must be obtained by patients based on medical indications referral to advanced PPK.

The Health Facilities owned by PPK 1 can affect the provision of referrals to KDP at an advanced level because the limited facilities possessed by KDP 1 can result in less than optimal service quality so that KDP 1 refers patients to Advanced KDP level. In addition, the availability of drugs in PPK 1 can also be a factor in providing referrals to hospitals because medicines are one of the supporting aspects in health services. Institutions that have limitations in providing medicines certainly cannot provide optimal services to patients so that they refer patients to hospitals. 
The next factor that can influence the provision of referrals by KDP 1 is the type of disease suffered by patients. Notoatmodjo (2012) explains that the diagnosis of diseases often referred to by hospital doctors is chronic diseases such as diabetes mellitus, hypertension, heart disease. If the hospital doctor is unable to make a diagnosis of the patient due to limited facilities supporting the diagnosis, or unable to handle patients with a diagnosis of certain diseases, then the hospital doctor must refer to the advanced level of KDP. The next factor that can influence the provision of referrals by doctors KDP 1 is the competence of doctors in KDP 1 . Ability is a region of knowledge and skills that are very important to achieve a work outcome.

\section{METHODS}

This research includes quantitative research with a Cross Sectional approach, namely the type of research that emphasizes the time of measurement or observation of data at one time at a time which is done on the dependent variable and the independent variable. This study consisted of five (5) variables, namely facilities, drug availability, type of disease, competence or quality of doctors and choosing referrals. In connection with the purpose of the study, overall this uses a survey method, namely research obtained from sampling a population and using a questionnaire as a basic data collection tool (Singarimbun, 2014). Research design with the aim of research to be achieved, if the purpose of the study is clear and in accordance with the formulation of the problem, the research and problem solving will run well. The first step in conducting research is to identify problems that are intended to reinforce the boundaries of the problem so that the scope of the research does not come out of its objectives. Followed by the decomposition of the background the problem does not come out of its purpose. Followed by deciphering the background of the problems intended to deliver and explain the background of the background problems and phenomena.

The population in the study were PPK I doctors in the Military District V / Brawijaya region and doctors in the Malang City area as many as 135 doctors. The sampling technique that will be used in this study is Non Propability Sampling which is purposive sampling where sampling techniques use certain considerations or choose according to the criteria of the researcher. The research object was limited to PPK I doctors in the V / Brawijaya Regional Military Region and in the Malang City region with the criteria of respondents being doctors who were in PPK I and practicing doctors, as well as Hospital doctors in Malang City as many as 135 people. With a total sample of 100 doctors. Sample calculation is done using the Slovin formula. The variables used in the study can be classified into: (1) independent variables, which are variables that explain and influence other variables, which consist of facilities (X1), drug availability (X2), types of disease (X3), and physician competence (X4), and (2) the dependent variable (i.e.), i.e. the variable explained and influenced by the independent variable. The dependent variable in this study is to choose a reference $(\mathrm{Y})$.

\section{RESULTS}

The results of descriptive statistical analysis for the characteristics of respondents are presented as follows:

Table 1 Characteristics of Respondents by Age

\begin{tabular}{cccc}
\hline No & Age & Frequency & Percentage \\
\hline 1 & $25-35$ years old & 16 & $16 \%$ \\
\hline 2 & $36-45$ years old & 34 & $34 \%$ \\
\hline 3 & $46-60$ years old & 46 & $46 \%$ \\
\hline 4 & $>60$ years old & 4 & $4 \%$ \\
\hline & Total & 100 & $100 \%$ \\
\hline
\end{tabular}

Data source: Primary data processed (2019) 
Based on table 1 above, out of 100 respondents, most of the patients' ages were 46-60 years old, $46 \%$. This means that there are a number of differences between patients who have ages 25-35, 36-45 years, 46-60 years and> 60 years in TK II Hospital Dr. Soepraoen Malang.

Tabel 2 Characteristics of Respondents by gender

\begin{tabular}{clccc}
\hline No & & Gender & Frequency & Percentage \\
\hline $\mathbf{1}$ & Male & & 56 & $56 \%$ \\
\hline $\mathbf{2}$ & Female & & 44 & $44 \%$ \\
\hline & & Total & 100 & $100 \%$ \\
\hline
\end{tabular}

Data source: Primary data processed (2019)

Based on table 2 of the 100 respondents it can be concluded that the majority of patients were $56 \%$, namely men. While the rest are women at $44 \%$. It can be concluded that there are some differences in the number of male and female patients at the Tk Hospital. II dr. Soepraoen Malang.

Tabel 3 Characteristics of Respondents by Doctor Section

\begin{tabular}{cccc}
\hline No & Dokter Bagian & Frequency & Percentage \\
\hline $\mathbf{1}$ & General & 100 & $100 \%$ \\
\hline $\mathbf{2}$ & Specialist & 0 & $0 \%$ \\
\hline & Total & 100 & $100 \%$ \\
\hline
\end{tabular}

Data source: Primary data processed (2019)

Based on Table 3 above, from 100 respondents it can be concluded that it can be concluded that the whole doctor in the hospital is Tk. II dr. Soepraoen Malang is a general practitioner. Meanwhile the specialist section does not have a doctor in this hospital.

Table 4 Characteristics of Respondents by Length of Work

\begin{tabular}{cccc}
\hline No & Length of Work & Frequency & Percentage \\
\hline $\mathbf{1}$ & $\leq 1$ tahun & 22 & $22 \%$ \\
\hline $\mathbf{2}$ & $>1$ tahun & 78 & $78 \%$ \\
\hline & Total & 100 & $100 \%$ \\
\hline
\end{tabular}

Data source: Primary data processed (2019)

Based on table 4 above from 100 respondents it can be concluded that the majority of doctors work for $>1$ year which amounts to $78 \%$. While the rest worked for $\leq 1$ years, which amounted to $22 \%$. It can be concluded that there are a number of differences between the length of time the doctor works at the Tk Hospital. II dr. Soepraoen Malang who worked for $>1$ year and $\leq 1$ year. 
Table 5 Value Category of Facility Variable

\begin{tabular}{ccccc}
\hline No & Average Value & Category & Frequency & Percentage \\
\hline $\mathbf{1}$ & $4.21-5.00$ & Very High/ Good & 38 & $38 \%$ \\
$\mathbf{2}$ & $3.41-4.20$ & High/Good & 40 & $40 \%$ \\
$\mathbf{3}$ & $2.61-3.40$ & Neutral & 12 & $12 \%$ \\
$\mathbf{4}$ & $1.81-2.60$ & Bad & 10 & $10 \%$ \\
$\mathbf{5}$ & $1.00-1.80$ & Very Bad/ Low & 0 & $0 \%$ \\
\hline \multicolumn{2}{r}{ Total } & & 100 & $100 \%$ \\
\hline
\end{tabular}

Data source: Primary data processed (2019)

Based on the results of the description that has been described, there is the highest mean value of 4.38 in the Very High / Good category.

Table 6 Value Category of Medicine Availability Variable

\begin{tabular}{ccccc}
\hline No & Average Value & Category & Frequency & Percentage \\
\hline $\mathbf{1}$ & $4.21-5.00$ & Very High/ Good & 42 & $42 \%$ \\
\hline $\mathbf{2}$ & $3.41-4.20$ & High/Good & 48 & $48 \%$ \\
\hline $\mathbf{3}$ & $2.61-3.40$ & Neutral & 6 & $6 \%$ \\
\hline $\mathbf{4}$ & $1.81-2.60$ & Bad & 4 & $4 \%$ \\
\hline $\mathbf{5}$ & $1.00-1.80$ & Very Bad/ Low & 0 & $0 \%$ \\
\hline & Jumlah & & 100 & $100 \%$ \\
\hline
\end{tabular}

Data source: Primary data processed (2019)

The results of the study on the availability of drugs variables obtained the highest value on the variables X2.2 and X2.3 with a value of 4.1 in the category of High / Good. For the overall average the average value is 4.00 in the High / Good category.

Table 7 Value Category of Type of Disease Variable

\begin{tabular}{ccccc}
\hline No & Average Value & Category & Frequency & Percentage \\
\hline $\mathbf{1}$ & $4.21-5.00$ & Very High/ Good & 60 & $60 \%$ \\
$\mathbf{2}$ & $3.41-4.20$ & High/Good & 20 & $20 \%$ \\
$\mathbf{3}$ & $2.61-3.40$ & Neutral & 10 & $10 \%$ \\
$\mathbf{4}$ & $1.81-2.60$ & Bad & 10 & $10 \%$ \\
$\mathbf{5}$ & $1.00-1.80$ & Very Bad/Low & 0 & $0 \%$ \\
\hline & Total & & 100 & $100 \%$
\end{tabular}

Data source: Primary data processed (2019)

Based on table 7 above, it is known that of the five questions found in the type of disease variable, the highest value is in the variables X3.4 and X3.5 with a value of 4.28 in the category of Very High / Good. For the overall average, the average score of 4.14 is included in the High / Good category. 
Table 8 Value Category of Doctor Compentence Variable

\begin{tabular}{ccccc}
\hline No & Average Value & Category & Frequency & Percentage \\
\hline $\mathbf{1}$ & $4.21-5.00$ & Very High/ Good & 44 & $44 \%$ \\
\hline $\mathbf{2}$ & $3.41-4.20$ & High/Good & 42 & $42 \%$ \\
\hline $\mathbf{3}$ & $2.61-3.40$ & Neutral & 4 & $4 \%$ \\
\hline $\mathbf{4}$ & $1.81-2.60$ & Bad & 10 & $10 \%$ \\
\hline $\mathbf{5}$ & $1.00-1.80$ & Very Bad/ Low & 0 & $0 \%$ \\
\hline & Total & & 100 & $100 \%$ \\
\hline
\end{tabular}

Data source: Primary data processed (2019)

Based on table 8 above the statement of indicators of the doctor's competency variable is included in the category of the highest statement on indicator X4.2 with an average value of 4.10 included in the category of High / Good. The average overall value is 4.01 in High / Good.

Table 9 Values Category of Conducting Referrals Variable

\begin{tabular}{ccccc}
\hline No & Average Value & Category & Frequency & Percentage \\
\hline $\mathbf{1}$ & $4.21-5.00$ & Very High/ Good & 38 & $38 \%$ \\
$\mathbf{2}$ & $3.41-4.20$ & High/Good & 42 & $42 \%$ \\
$\mathbf{3}$ & $2.61-3.40$ & Neutral & 10 & $10 \%$ \\
$\mathbf{4}$ & $1.81-2.60$ & $\mathrm{Bad}$ & 10 & $10 \%$ \\
$\mathbf{5}$ & $1.00-1.80$ & Very Bad/ Low & 0 & $0 \%$ \\
\hline & Jumlah & & 100 & $100 \%$ \\
\hline
\end{tabular}

Data source: Primary data processed (2019)

Based on table 9 above the variable indicator statement makes a reference obtained the highest value on indicators Y1.2 and Y1.3 with a result of 4.06 and included in the category High / Good. The overall average value is 3.96 in the category of Fair High / Good.

The $\mathrm{T}$ test is a test used to determine whether the independent variables partially have a significant or no effect on the dependent variable, the degree of significance used is 0.05 . Based on the results of the SPSS 17 test, the results of the T test are in table 10 as follows:

Table 10 T-Test Result

\begin{tabular}{clcccc}
\hline No & Variable & t-count & $\begin{array}{c}\text { t-table } \\
\text { (standard) }\end{array}$ & Sig. & Description \\
\hline 1 & Facility & 4.300 & 2.000 & 0.000 & Significant \\
\hline 2 & Medicine Availability & 2.557 & 2.000 & 0.000 & Significant \\
\hline 3 & Types of Disease & 2.435 & 2.000 & 0.000 & Significant \\
\hline 4 & Doctor Competence & 2.327 & 2.000 & 0.000 & Significant \\
\hline
\end{tabular}

Data source: Primary data processed (2019)

The t-test (partial) statistical test shows the influence of facilities, drug availability, type of disease, and physician competence in choosing referrals $(\mathrm{Y})$ is partially influential. Based on the table above, it can be described as follows, namely: 
Facility variable (X1) has a significance value (Sig.) 0,000 in the Coefficientsa table with a value of $\alpha$ (significance degree) 0.05 meaning $0.003<0.05$ or there is a significant effect and the $t$ test shows $4.300>t$ table $(2,000)$. This means that facilities have a significant effect on choosing referrals. The drug availability variable (X2) has a significance value (Sig.) 0,000 in the Coefficientsa table with a value of $\alpha$ (significance degree) 0.05 meaning $0.006<0.05$ or there is a significant effect and the $t$ test shows $2.557>t$ table $(2,000)$. This means that the availability of drugs has a significant effect on choosing a referral.

The type of disease variable (X3) has a significance value (Sig.) 0,000 in the Coefficientsa table with a value of $\alpha$ (significance degree) 0.05 meaning $0.006<0.05$ or there is a significant influence and the $\mathrm{t}$ test shows 2.435> t table $(2,000)$. This means that the type of disease has a significant effect on choosing a referral.

Physician competency variable (X4) has a significance value (Sig.) 0.006 in the Coefficientsa table with a value of $\alpha$ (significance degree) 0.05 which means $0.006<0.05$ or there is a significant effect and $t$ test shows $2.327>t$ table $(2,000)$. This means that physician competence has a significant effect on choosing referrals.

\section{DISCUSSION}

\section{A. The Effect of Availability of Facilities in PPK level 1 on Patient Referral Selection to RS Tk. II dr. Soepraoen Malang}

One of the important things for a health agency is the facility. Facilities are a means to facilitate the implementation of functions. Based on the data analysis that has been carried out in the study, it can be seen that there is an influence between the availability of facilities and the selection of patient goals to RS Tk II dr. Soepraoen Malang. That is, the better and higher level of availability of facilities will affect the higher the selection of patient referrals to RS Tk II dr. Soepraoen Malang. Conversely, the lower availability of facilities will affect the lower selection of patient referrals to the hospital.

In accordance with the results of the study on variable availability of facilities. Data with the highest results of 4.38 found in the indicator about "Registration services are always available at all times" on this indicator obtained the highest value because this hospital serves registration at any time as well as online registration making it easier for patients to be referred to this hospital. From facilitator variables there are disadvantages and advantages, among others, the lack of facility variables in RS Tk II dr. Soepraoen Malang is a medical and non-medical equipment available at RS Tk II dr. Soepraoen Malang is incomplete, while for the advantages of the facility variable is the fulfillment of the existing standard indicators of the facility itself so that there is a significant effect.

Influence between the two can occur because facilities are important things for a health agency. Facilities are a means to facilitate and facilitate the implementation of functions. Whereas referral is a system of administering health services that implements the delegation of reciprocal responsibility to a case of a disease or health problem vertically in the sense of a unit that is less capable of a unit that is more capable or horizontally in the sense of units of equal capacity. Usually, one reason doctors make referrals is because hospitals that currently handle patients are no longer able for many reasons, one of which is inadequate equipment or facilities, so doctors will refer patients to other hospitals that have more adequate facilities. support patient recovery.

\section{B. The Effect of Medicine Availability in PPK level 1 on Patient Referral Selection to RS Tk. II dr. Soepraoen Malang}

Medicines are chemicals that can affect biological tissues, and according to WHO, drugs are substances that can affect physical or psychological activity. Based on the data analysis that has been done in the study, it can be seen that there is an influence between the availability of medicines and the selection of patient referrals to RS Tk II dr. Soepraoen Malang. Specifically, the better and higher levels of medicine availability will affect the higher the selection of patient referrals to RS Tk II dr. Soepraoen Malang. Conversely, the lower availability of medicines will affect the lower selection of patient referrals to the hospital. In accordance with the research data on the variable availability of 
drugs. The highest variable value data on indicators X2.2 and X2.3 with a value of 4.1. X2.2 namely in the statement "RS always updates on new drugs for the needs of patients", this is because the TK II hospital Dr. Soepraoen always updates the drugs available in pharmacy.

From the availability of medicines variables, there are disadvantages and advantages, the disadvantage is RS Tk II dr. Soepraoen Malang does not have a fast and easy service in providing drug needs for patients while for the advantages of the variable availability of drugs is the fulfillment of elements in the indicator of the availability variable of the drug itself so that there is a significant effect. The results of this study are supported by the results of research conducted by Alawi et al (2012). The Alawi (2012) study shows that in choosing referrals, hospitals choose health agencies that have higher availability of drugs and facilities. One reason doctors make referrals is because hospitals that currently handle patients are no longer able for many reasons, one of which is the unavailability of medicines needed, so doctors will refer patients to other hospitals that have adequate drug availability, which is in accordance with the disease suffered by the patient so that the patient's recovery can be realized more quickly.

\section{The Effect of Disease Type in PPK level 1 on Patient Referral Selection to RS Tk. II dr. Soepraoen Malang}

In recommending referrals for patients, the doctor will consider the type of disease suffered by the patient, whether the disease suffered by the patient can be cured and handled by the hospital to be addressed. One of the factors that influence Level I PPK doctors to provide referrals is the type of illness suffered by patients treated in that place. This is due to the limited ability of doctors in PPK to treat patients with certain types of diseases the ability of the doctor.

Based on the results of the study, it is known that this type of disease has a significant effect on choosing referrals, according to the results of research in table 4.9 with the highest average values found in X3.4 and X3.5 variables with a value of 4.28 in the X3.4 statement namely " The hospital did the best way to deal with patients, both minor and severe illnesses, "the results of the indicators stated that the Soepraon hospital provided the best in handling patients. And next, namely X3.5 in the statement "RS has medical services supporting specialists for handling patient diseases such as anesthesiology, radiology, pathology, anatomical pathology and medical rehabilitation".

From the types of diseases there are disadvantages and advantages, among others, the lack of variable types of disease in RST, Dr. Soepraoen Malang is RST Dr. Soepraoen Malang does not yet have sophisticated tools to deal with certain types of diseases and the availability of rapid treatment for various types of diseases that are not yet adequate. While for the advantages of the type of disease variable is the fulfillment of the elements in the indicator variable type of the disease itself so that there is a significant effect. Based on this, it can be concluded that in recommending referrals for patients, the doctor will consider the type of illness suffered by the patient, whether the disease suffered by the patient can be cured and handled by the hospital to be addressed.

\section{The Effect of Doctor Competence in PPK level 1 on Patient Referral Selection to RS Tk. II dr. Soepraoen Malang}

Competence according to the Decree of the Minister of National Education No. 045 / U / 2017 is "a set of intelligent and responsible actions that a person has as a condition to be considered capable by the community in carrying out tasks in certain occupations". The doctor's competency factor can influence the referral factor given by the PPK I doctor to the patient because the health service is a service that is very dependent on the doctor's competence so that doctors with low quality competencies tend to be less able to handle certain diseases so that they provide referral to patients in other hospitals that have better doctor competence.

Based on the results of the study, it is known in table 4.11 Variable competence of doctors. The data of the highest variable description results on indicator X4.2 with an average value of 4.10 in the statement "RS has all specialist doctors in their respective fields", this is due to having all specialist doctors in various fields. From the variable competence of doctors there are disadvantages and advantages, among others, the lack of variable competence of doctors in RST, Dr. Soepraoen Malang is RST Dr. Soepraoen Malang does not yet have a doctor with expert qualifications in treating 
patients' diseases. As for the advantages of the doctor's competency variable is the fulfillment of elements in the indicators of the doctor's competency variable itself so that there is a significant influence. The results of this study support the results of a study conducted by Alawi et al (2017) which states that the factors related to the high referral of non-specialistic cases of national health insurance patients in Sukabumi District Hospital in 2015 are categories of hospitals by region, drug adequacy and adequacy medical devices in hospitals and the distance of hospitals to referral facilities. Based on the explanation described above, it can be concluded that the selection of referrals can be influenced by the level of competence of the doctor.

\section{CONCLUSION} follows:

Based on the results of the research and discussion, conclusions were obtained in the study as

1. Hospital facilities have a significant influence on choosing a referral, where the more complete the hospital facilities the level in choosing a patient hospital referral during treatment at the Hospital. II dr. Soepraoen will be even higher.

2. The availability of drugs has a significant effect on choosing a referral, where the more complete the availability of drugs, the level of choosing patient referrals during treatment at the Hospital. II dr. Soepraoen will get better.

3. The type of disease has a significant influence on choosing a referral, where the more complete treatment for the type of disease that is able to be handled then the level of choosing patient referrals during treatment at the Hospital. II dr. Soepraoen will be even higher.

4. Doctor competency has a significant influence on choosing a referral where the better the quality of service provided by the hospital, the level of comfort of patients during treatment at the Hospital. II dr. Soepraoen will be even higher.

5. Simultaneously for each facility variable, drug availability, type of disease and physician competence can have a significant effect on choosing referrals. So the better and the higher the facilities, the availability of drugs, the type of disease and the competence of doctors given by the Hospital. II dr. Soepraoen, the level of selection of patient referrals during treatment will also be higher.

\section{SUGGESTION}

1. Hospital: management of the provision of facilities at Tk II Hospital Dr. Soepraoen regarding the response of patients to the quality of services needed by facilities for patients receiving care.

2. Next researcher: development of science in the field of hospital administration and as a basis for developing research on the quality of health services in hospitals and can find out the basis of data processing in research.

3. The low analysis of factors that influence the doctor's decision in choosing patient referrals to the TK hospital. II dr. Soepraoen Malang can be minimized by further increasing the indicator indicators of each variable that is considered still low.

\section{REFERENCES}

Alawi, Masykur, Junadi, P., \& Latifah, S., N. (2017). Analisis Faktor-Faktor yang Berhubungan dengan Tingginya Rujukan Kasus Non Spesialistik Pasien Jaminan Kesehatan Nasional pada Rumah Sakit diKabupaten Sukabumi Tahun 2015. Jurnal Ekonomi Kesehatan Indonesia, Vol. 2 No. 1.

Kemendikbud RI. (2017). Surat Keputusan Menteri Pendidikan Nasional No. 045/U/2017 Tentang Kurikulum Pendidikan Tinggi. Jakarta: Departemen Pendidikan Nasional.

Kementerian Kesehatan. (1993). Peraturan Menteri Kesehatan RI Nomor 922/MENKES/PER/X/1993 tentang Ketentuan dan Tata Cara Pemberian Izin Apotek. Jakarta: Kementerian Kesehatan Republik Indonesia. 
Kementerian Kesehatan. (2012). Peraturan Menteri Kesehatan No.001 Tahun 2012 tentang Sistem Rujukan Pelayanan Kesehatan Perorangan. Jakarta: Kementerian Kesehatan Republik Indonesia.

Notoatmojo, S. (2012). Metodologi penelitian kesehatan. Jakarta: Rineka Cipta.

Permenkes. (2013). Peraturan Menteri Kesehatan Nomor 6 Tahun 2013, tentang Kriteria Fasilitas Pelayanan Kesehatan Terpencil, Sangat Terpencil, dan Fasilitas Pelayanan Kesehatan Yang Tidak Diminati.

Singarimbun, Masri, \& Effendi, S. (2014). Metode Penelitian Survei. Jakarta: LP3ES. 